\title{
PENGARUH PENERAPAN SISTEM AKUNTANSI PEMERINTAH DAERAH, PEMAHAMAN AKUNTANSI, DAN KETAATAN PADA PERATURAN PERUNDANGAN TERHADAP AKUNTABILITAS KINERJA INSTANSI PEMERINTAH (Studi Kasus Pada Organisasi Perangkat Daerah Kota Kendari)
}

\author{
Hasbuddin $^{1}$, Husin ${ }^{2}$, Yusna Herman ${ }^{3}$ \\ Jurusan Akuntansi Fakultas Ekonomi dan Bisnis Universitas Halu Oleo Kendari \\ Sulawesi Tenggara
}

\begin{abstract}
ABSTRAK
Penelitian ini bertujuan untuk mengetahui pengaruh sistem akuntansi pemerintah daerah, pemahaman akuntansi, dan ketaatan pada peraturan perundangan terhadap akuntabilitas kinerja instansi pemerintah. Penelitian ini menggunakan data primer. Pengumpulan data menggunakan penyebaran kuesioner. Populasi dari penelitian ini yaitu seluruh organisasi perangkat daerah (OPD) di Kota Kendari dan metode pengambilan sampel dilakukan dengan metode sampel acak sederhana, sampel dalam penelitian ini sebanyak 22 OPD, dimana setiap OPD terdapat 3 responden sehingga jumlah sampel untuk penelitian ini sebanyak 66 amatan, kemudian diuji menggunakan Analisis Deskriptif dan Uji Inferensial. Hasil penelitian ini adalah 1). sistem akuntansi pemerintah daerah secara parsial dan simultan berpengaruh positif dan signifikan terhadap akuntabilitas kinerja instansi pemerintah daerah Kota Kendari. 2). pemahaman akuntansi secara parsial dan simultan berpengaruh positif dan tidak signifikan terhadap akuntabilitas kinerja pemerintah daerah Kota Kendari. 3). ketaatan pada peraturan perundangan secara parsial dan simultan berpengaruh positif dan signifikan terhadap Akuntabilitas Kinerja Instansi Pemerintah Daerah Kota Kendari.
\end{abstract}

\section{Kata Kunci : Akuntabilitas Kinerja Instansi Pemerintah, Sistem Akuntansi Pemerintah Daerah, Pemahaman Akuntansi, Ketaatan Peraturan Perundangan.}

\begin{abstract}
This study aims to determine the effect of implementation local government accounting system, the understanding of accounting, and the adherence of the law regulation on the performance accountability of goverment institution. This study uses primary data. Data collection using questionnaire distribution. The population of this research is all regional apparatus organization OPD in Kendari district and sampling method is done by Simple Random Sampling method, the sample in this research is 22 OPD, where each OPD there are 3 respondents so that the number of samples for this study as much as 66 observations, then tested using Descriptive Analysis and inferential test. The results of this study were 1). implementation local government accounting system partially and simultaneously positive effect and significant on the performance of
\end{abstract}


Jurnal Akuntansi dan Keuangan (JAK)

Volume 6, No. 2 Oktober Tahun 2021

Page: 331 - 346

http://ojs.uho.ac.id/index.php/jak-uho/issue/archive

e-ISSN: 2088-4656

accountability of goverment institution. 2). understanding of accounting partially and simultaneously positive effect and not significant on the performance of accountability of goverment institution. 3). Compliance to the laws and regulations partially and simultaneously positive effect and significant on the performance of accountability of goverment institution.

keywords: Performance Of Accountability Of Goverment Institution, Local

Government Accounting System, Understanding Of Accounting, Compliance To The Laws And Regulations.

\section{PENDAHULUAN}

Dalam proses penyiapan laporan keuangan pemerintah daerah diperlukan dukungan pengetahuan akuntansi yang memadai atas standar yang mengatur penyusunan laporan keuangan instansi pemerintah. Mardiasmo (2002) menegaskan bahwa sistem pertanggungjawaban keuangan suatu institusi dapat berjalan dengan baik, bila terdapat mekanisme pengelolaan keuangan yang baik pula. Pemahaman sistem akuntansi merupakan faktor lain yang perlu untuk dicermati, karena untuk dapat menyajikan informasi keuangan yang memadai dalam bentuk pelaporan keuangan yang dapat dipahami oleh pengguna, maka harus dilakukan oleh personel yang memiliki kompetensi di bidang pengelolaan keuangan daerah.

Ketaatan pada peraturan perundangan juga merupakan elemen penting yang secara langsung berkaitan dengan kinerja instansi pemerintah. Dengan adanya hal ini diharapkan laporan akuntabilitas yang dihasilkan tepat dan sesuai dalam rangka pemenuhan kewajiban terhadap pemerintah pusat dan kebutuhan informasi publik. Akan tetapi kurangnya ketaatan dan kepedulian atas penerapan sistem akuntansi pemerintah daerah yang sesuai dengan peraturan yang berlaku masih banyak terjadi di daerah - daerah yang terdapat di Indonesia.

Pemerintah Kota Kendari, Sulawesi Tenggara (Sultra), mendapat catatan prestasi dalam penyelenggaraan pemerintah yakni dengan memperoleh penghargaan SAKIP atau Sistem Akuntabilitas Instansi Pemerintah tahun 2019 dengan predikat B dari Menpan RB (sultra.antaranews.com). Meskipun begitu, hasil evaluasi SAKIP tahun 2019 yang diperoleh pemerintah Kota Kendari adalah "B" atau tetap sama seperti tahun 2018 yang lalu. Hasil capaian ini merupakan buah dari sinergitas kerjasama, kolaborasi, dan koordinasi serta harmonisasi antara seluruh Organisasi Perangkat Daerah dan jajarannya sampai pada tingkat kecamatan dan kelurahan di lingkup pemerintah Kota 
Jurnal Akuntansi dan Keuangan (JAK)

Volume 6, No. 2 Oktober Tahun 2021

Page: 331 - 346

http://ojs.uho.ac.id/index.php/jak-uho/issue/archive

e-ISSN: $2088-4656$

Kendari. Pemerintah Kota Kendari mengharapkan dengan adanya capaian ini agar Akuntabilitas Kinerja yang meliputi komponen perencanaan kinerja, pengukuran kinerja, pelaporan kinerja, evaluasi kinerja dan capaian kinerja akan terus ditingkatkan lagi di tahun - tahun mendatang agar bisa mencapai "BB" atau bahkan mencapai "A".

Penelitian kali ini dengan berpedoman pada literatur yang telah ada akan mencoba untuk menganalisis pengaruh penerapan sistem akuntansi pemerintah daerah, pemahaman akuntansi, dan ketaatan pada peraturan perundangan terhadap akuntabilitas kinerja instansi pemerintah, khususnya pada Organisasi Perangkat Daerah (OPD) di Kota Kendari. Penelitian ini akan menggunakan objek penelitian OPD di Kota Kendari. Alasan dilakukan penelitian pada OPD di Kota Kendari adalah karena dalam dua tahun berturut turut Kota Kendari meraih penghargaan SAKIP dengan predikat "B" yaitu pada tahun 2018 dan 2019, dengan ini maka pemerintah kota mengharapkan agar Akuntabilitas Kinerja di setiap OPD perlu ditingkatkan lagi agar di tahun berikutnya dapat memeperoleh predikat yang lebih baik. Maka dari itu, Saya sebagai peneliti tertarik untuk meneliti akuntabilitas di Kota Kendari karena saya ingin mengetahui tinggkat Akuntabilitas kinerja di OPD Kota Kendari apakah sudah disajikan secara transparan, dapat dipertanggungjawabkan, dan disusun sesuai dengan Standar yang telah ditetapkan. Bagaimana Sistem Akuntansi Pemerintah Daerah terlaksana di tiap OPD Kota Kendari apakah sudah diterapkan dengan baik untuk penyusunan Laporan Keuangan dilingkungan pemerintahan daerah. Pemahaman akuntansi dan ketaatan pada peraturan perundangan juga menjadi elemen penting dalam akuntabilitas kinerja. Saya ingin mengetahui seberapa besar pemahaman akuntansi pegawai/karyawan yang mengelola keuangan dan ketaatan pada peraturan perundangan yang telah menetapkan peraturan mengenai keuangan daerah dan penyusunan laporan keuangan pemerintahan daerah.

Penelitian ini memiliki tujuan untuk mengetahui bagaimana pengaruh penerapan sistem akuntansi pemerintah daerah pemahaman akuntansi, dan ketaatan pada peraturan perundangan terhadap akuntabilitas kinerja instansi Pemerintah, khususnya pada OPD di Kota Kendari. 
Jurnal Akuntansi dan Keuangan (JAK)

Volume 6, No. 2 Oktober Tahun 2021

Page: 331 - 346

http://ojs.uho.ac.id/index.php/jak-uho/issue/archive

e-ISSN: 2088-4656

\section{LANDASAN TEORI DAN HIPOTESIS}

\section{Akuntabilitas Kinerja Instansi Pemerintah}

Akuntabilitas dapat diartikan sebagai perwujudan pertanggungjawaban seseorang atau unit organisasi, dalam mengelola sumber daya yang telah diberikan dan dikuasai, dalam rangka pencapaian tujuan, melalui suatu media berupa laporan akuntabilitas kinerja secara periodik. Akuntabilitas Kinerja Instansi Pemerintah (AKIP), sebagaimana dimaksud dalam Peraturan Pemerintah Nomor 8 Tahun 2006 tentang Pelaporan Keuangan dan Kinerja Instansi Pemerintah, Instruksi Presiden Nomor 7 Tahun 1999 tentang Akuntabilitas Kinerja Instansi Pemerintah dan Peraturan Menteri Pendayagunaan Aparatur Negara dan Reformasi Birokrasi Nomor 29 Tahun 2010 tentang Pedoman Penyusunan Penetapan Kinerja dan Laporan Akuntabilitas Kinerja Instansi Pemerintah, dibangun dan dikembangkan dalam rangka mewujudkan pertanggungjawaban pelaksanaan tugas dan fungsi serta pelaksanaan program instansi pemerintah. Setiap instansi pemerintah wajib mengkomunikasikan pencapaian tujuan dan sasaran strategis organisasi kepada para stakeholders, yang dituangkan melalui Laporan Akuntabilitas Kinerja Instansi Pemerintah (LAKIP).

\section{Sistem Akuntansi Pemerintah Daerah (SAPD)}

Sistem adalah suatu cara tertentu dan bersifat repetitif untuk melaksanakan suatu atau sekelompok aktivitas. Sistem memiliki karakteristik berupa rangkaian langkahlangkah yang berirama, terkoordinasi dan berulang yang dimaksud untuk mencapai suatu tujuan tertentu (Anthony dan Govindajaran, 2005). Akuntansi merupakan suatu sistem. Sistem adalah suatu kesatuan yang terdiri atas subsistem-subsistem atau kesatuan yang lebih kecil, yang berhubungan satu sama lain dan mempunyai tujuan tertentu. Suatu sistem mengolah input (masukan) menjadi output (keluaran). Input sistem akuntansi adalah bukti-bukti transaksi dalam bentuk dokumen atau formulir. Outputnya adalah laporan keuangan

\section{Pemahaman Akuntansi}

Pemahaman akuntansi diartikan sebagai suatu kemampuan dari seseorang pegawai/karyawan yang mengelola keuangan untuk mengolah suatu informasi akuntansi 
Jurnal Akuntansi dan Keuangan (JAK)

Volume 6, No. 2 Oktober Tahun 2021

Page: 331 - 346

http://ojs.uho.ac.id/index.php/jak-uho/issue/archive

e-ISSN: $2088-4656$

dan kemudian menyusun informasi tersebut ke dalam bentuk laporan keuangan yang disusun sesuai dengan standar yang telah ditetapkan oleh pemerintah. Dalam proses penyusunan dan penyajian laporan keuangan, adanya pemahaman aparat pemerintah adalah suatu hal yang sangat mempengaruhi, dimana jika pegawai mampu untuk mengolah suatu informasi akuntansi dan mengerti dengan sumber yang telah ditetapkan oleh pemerintah untuk penyusunan dan penyajian laporan keuangan maka laporan yang disusun dan disajikan akan sesuai dengan standar, akan berkualitas, dan relevan untuk pengambilan keputusan.

\section{Ketaatan Pada Peraturan Perundangan}

Sistem hukum yang berlaku di suatu negara tergantung pada sistem yang dianutnya, apakah negara yang bersangkutan menganut Civil Law atau Common Law. Dengan civil law maka segala sesuatu aktivitas didasarkan pada peraturan perundangan, termasuk di dalamnya aturan - aturan terkait dengan akuntansi terakumulasi dalam suatu perundangan dan aturan ini memiliki kecenderungan sangat terstruktur dan prosedural. Sebaliknya, common law segala kegiatan didasarkan kepada kesepakatan politik yang dikembangkan berdasarkan kasus demi kasus. Dalam sistem ini, membebaskan badan-badan pemerintah menggunakan standar apapun, yang penting berterima umum.

Sistem hukum yang dianut dalam sistem akuntansi sektor publik adalah sistem civil law, dimana setiap aturan yang berhubungan dengan akuntansi sektor publik yang dimuat dalam bentuk peraturan perundangan. Dalam menyusun laporan keuangan, pemerintah harus memenuhi persyaratan minimum yang ditentukan dalam standar akuntansi pemerintahan. Hal ini disebabkan oleh karena standar akuntansi berisikan prinsip-prinsip yang menunjang penyajian informasi keuangan pemerintah yang relevan, handal, dapat dibandingkan dan dipahami.

\section{Penelitiaan Terdahulu}

Ada beberapa penelitian yang dijadikan peneliti sebagai acuan dalam melakukan penelitian ini, yaitu beberapa diantaranya ialah:

Zirman, dkk (2010) melakukan penelitian tentang Pengaruh Kompetensi 
Jurnal Akuntansi dan Keuangan (JAK)

Volume 6, No. 2 Oktober Tahun 2021

Page: 331 - 346

http://ojs.uho.ac.id/index.php/jak-uho/issue/archive

e-ISSN: $2088-4656$

Aparatur Pemerintah Daerah, Penerapan Akuntabilitas Keuangan, Motivasi Kerja, Dan

Ketaatan Pada Peraturan Perundangan Terhadap Akuntabilitas Kinerja Instansi Pemerintah. Hasil penelitian menunjukkan bahwa ketaatan pada peraturan perundangan berpengaruh signifikan terhadap akuntabilitas kinerja sedangkan kompetensi aparatur pemerintah daerah, akuntabilitas keuangan, dan motivasi kerja tidak berpengaruh signifikan terhadap akuntabilitas kinerja.

Riantiarno dan Azlina (2011) dengan judul penelitian "Faktor-faktor yang Mempengaruhi Kinerja Instasi Pemerintah". Hasil penelitian membuktikan bahwa ketaatan peraturan perundangan berpengaruh terhadap akuntabilitas kinerja sedangkan penerapan akuntabilitas keuangan tidak berpengaruh terhadap akuntabilitas kinerja.

Mulyana (2006) melakukan penelitian tentang Pengaruh Penyajian Neraca Daerah Dan Aksesibilitas Laporan Keuangan Terhadap Transparansi Dan Akuntabilitas Pengelolaan Keuangan Daerah. Hasil penelitian menunjukkan bahwa aksesibilitas laporan keuangan berpengaruh positif dan signifikan terhadap transparansi dan akuntabilitas keuangan daerah.

Darwanis dan Chairunnisa (2013) melakukan penelitian tentang Akuntabilitas Kinerja Instansi Pemerintah. Hasil penelitian yaitu penerapan akuntansi keuangan daerah, pengawasan kualitas laporan keuangan, dan kejelasan sasaran anggaran secara simultan berpengaruh terhadap akuntabilitas kinerja instansi pemerintahan Aceh. Penerapan akuntansi keuangan daerah berpengaruh secara parsial terhadap akuntabilitas kinerja instansi pemerintahan Aceh. Pengawasan kualitas laporan keuangan berpengaruh secara parsial terhadap akuntabilitas kinerja instansi pemerintah Aceh. Kejelasan sasaran anggaran tidak berpengaruh terhadap akuntabilitas kinerja instansi pemerintah Aceh.

Janny Rahmi Hasibuan (2018) melakukan penelitian tentang Pengaruh Penerapan Sistem Akuntansi Pemerintah Daerah, Pemahaman Akuntansi, Dan Ketaatan Pada Peraturan Perundangan Terhadap Akuntabilitas Kinerja Instansi Pemerintah Pada SKPD Padang Lawas. Hasil penelitian menunjukkan sistem akuntansi pemerintah daerah, pemahaman akuntansi, dan ketaatan pada peraturan perundangan secara parsial dan simultan memiliki pengaruh signifikan terhadap akuntabilitas kinerja instansi pemerintah pada SKPD Kabupaten Padang Lawas. 
Jurnal Akuntansi dan Keuangan (JAK)

Volume 6, No. 2 Oktober Tahun 2021

Page: 331 - 346

http://ojs.uho.ac.id/index.php/jak-uho/issue/archive

e-ISSN: 2088-4656

\section{Paradigma Penelitian}

Menurut Sugiyono (2014:93) mengemukakan bahwa kerangka berpikir merupakan model konseptual tentang bagaimana teori berhubungan dengan berbagai faktor yang telah di identifikasi sebagai masalah penting. Berdasarkan latar belakang masalah dan tinjauan teoritis yang telah diuraikan sebelumnya, peneliti membuat kerangka pikir penelitian sebagai berikut:

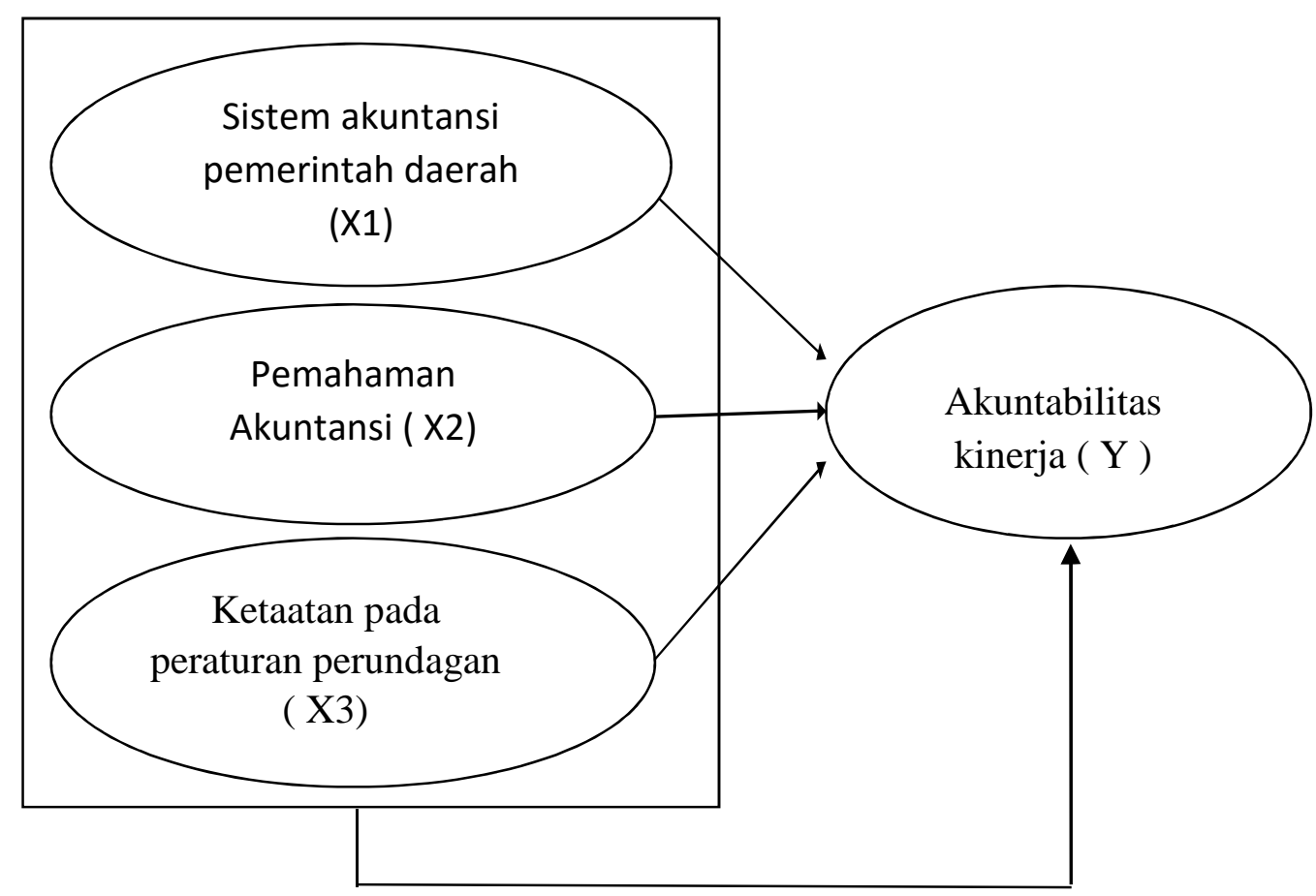

Gambar 1

Paradigma Penelitian

Hipotesis dalam penelitian ini adalah Sistem Akuntansi Pemerintah Daerah (SAPD) secara parsial dan simultan berpengaruh terhadap Akuntabilitas Kinerja Instansi Pemerintah pada OPD Kota Kendari, Pemahaman akuntansi secara parsial dan simultan berpengaruh terhadap Akuntabilitas Kinerja Instansi Pemerintah pada OPD Kota Kendari, Ketaatan pada Peraturan Perundangan secara parsial dan simultan berpengaruh terhadap Akuntabilitas Kinerja Instansi Pemerintah pada OPD Kota Kendari. 
Jurnal Akuntansi dan Keuangan (JAK)

Volume 6, No. 2 Oktober Tahun 2021

Page: 331 - 346

http://ojs.uho.ac.id/index.php/jak-uho/issue/archive

e-ISSN: $2088-4656$

\section{METODE PENELITIAN}

Objek penelitian dalam Penelitian ini adalah Sistem Akuntansi Pemerintah Daerah, Pemahaman Akuntansi, dan Ketaatan Pada Peraturan Perundangan sebagai variabel independen dan Akuntabilitas kinerja Instansi Pemerintah sebagai Variabel dependen pada OPD Kota Kendari. Populasi dalam penelitian ini adalah seluruh OPD di Kota Kendari. Pemilihan sampel penelitian dilakukan dengan menggunakan metode pengambilan sampel acak sederhana (simple random sampling), yaitu hanya sebagian saja dari OPD Kota Kendari yang dijadikan sampel. Responden yang digunakan dalam penelitian ini adalah Kepala OPD, Kepala bagian keuangan dan Kepala Sub bagian keuangan pemerintah pada setiap OPD yang akan dilakukan penelitian di Kota Kendari. Peneliti mengasumsikan setiap OPD menyerahkan 3 kuisioner, dengan adanya jumlah OPD sebanyak 22 OPD yang akan diteliti, maka yang akan diteliti sebanyak 66 responden.

Data yang digunakan dalam penelitian ini adalah data primer. Dalam penelitian ini, data yang digunakan untuk mengumpulkan data primer ini adalah melalui daftar pertanyaan yang disebut kuesioner. Media kuesioner akan memberikan beberapa pilihan jawaban alternatif yang sesuai dengan proporsi dari masing-masing pernyataan. Metode analisis data yang digunakan dalam penelitian ini adalah metode analisis deskriptif dan uji inferensial.

\section{HASIL PENELITIAN DAN PEMBAHASAN}

\section{Hasil Penelitian}

Variabel independen dalam penelitian ini adalah Sistem Akuntansi Pemerintah Daerah (X1), Pemahaman Akuntansi (X2), dan Ketaatan Pada Peraturan Perundangan (X3) dan variabel dependen adalah Akuntabilitas Kinerja Instansi Pemerintah (Y). Hasil penelitian deskripsi variabel Sistem Akuntansi Pemerintah Daerah, Pemahaman Akuntansi, dan Ketaatan Pada Peraturan Perundangan menurut tanggapan responden sudah baik. Hal ini dibuktikan dengan nilai persepsi rata rata keseluruhan masing masing variabel adalah $(X 1=4,51),(X 2=4,21)$, dan $(X 3=4,25)$. Selanjutnya untuk hasil deskripsi variabel Akuntabilitas Kinerja Instansi Pemerintah juga dikategorikan sudah baik. Hal ini dibuktikan dengan nilai persepsi rata rata keseluruhan variabel Akuntabilitas Kinerja Instansi Pemerintah sebesar 4,23. 
Jurnal Akuntansi dan Keuangan (JAK)

Volume 6, No. 2 Oktober Tahun 2021

Page: 331 - 346

http://ojs.uho.ac.id/index.php/jak-uho/issue/archive

e-ISSN: 2088-4656

Hasil uji validitas dan reabilitas pada penelitian ini menunjukkan hasil yang valid dan reliabel. Keputusan ini diambil karena koefisien korelasi (pearson correlation) yang mendapat nilai lebih besar dari $r_{\text {tabel }}=0.246$ dengan tingkat signifikan 0,000 sehingga dikatakan valid, dan dikatakan reliabel karena nilai koefisien alpha keempat variabel lebih besar dari 0,60 berarti reliable.

Hasil uji asumsi klasik pada uji normalitas dapat diketahui pada grafik Normal Probability Plot (P-P Plot Test) dan grafik histogram, yang dimana pada grafik Normal Probability Plot titik titik pada grafik tersebut menyebar di sekitar garis diagonal dan juga mengikuti arah garis diagonal, sehingga model regresi layak dipakai karena data dari masing masing variabel telah terdistribusi secara normal. Begitu halnya dengan grafik histogram dimana residual terdistribusi secara normal ditunjukkan dengan pola yang terbentuk simetris, tidak melenceng ke kanan atau ke kiri. Hasil uji heterokedastisitas dilakukan melalui Scatter Plot (diagram pancar) yang menunjukkan bahwa titik-titik yang ada menyebar secara acak, tersebar baik di atas maupun di bawah angka nol pada sumbu Y dan tidak membentuk sebuah pola tertentu yang jelas. Oleh karena itu, model regresi dikatakan tidak mengalami heteroskedastisitas. Selanjutnya uji multikolinearitas dengan melihat nilai tolerance dan VIF, dimana menunjukkan hasil bahwa masing-masing nilai VIF tidak lebih besar dari 10 dan nilai tolerance diatas 0.1 maka tidak terdapat gejala multikolinearitas.

Hasil estimasi regresi linear berganda pengaruh Sistem Akuntansi Pemerintah Daerah, Pemahaman Akuntansi, dan Ketaatan Pada Peraturan Perundangan terhadap Akuntabilitas Kinerja Instansi Pemerintah disajikan pada tabel berikut:

Tabel 1

Hasil Uji Regresi Berganda

Coefficients $^{\mathbf{a}}$

\begin{tabular}{|c|c|c|c|c|c|c|c|c|c|c|}
\hline \multirow[t]{2}{*}{ Model } & \multicolumn{2}{|c|}{$\begin{array}{l}\text { Unstandardize } \\
\text { d Coefficients }\end{array}$} & $\begin{array}{c}\text { Standardize } \\
\mathrm{d}\end{array}$ & \multirow[t]{2}{*}{$\mathrm{T}$} & \multirow[t]{2}{*}{ Sig. } & \multicolumn{3}{|c|}{ Correlations } & \multicolumn{2}{|c|}{$\begin{array}{c}\text { Collinearity } \\
\text { Statistics }\end{array}$} \\
\hline & B & $\begin{array}{l}\text { Std. } \\
\text { Error }\end{array}$ & Beta & & & $\begin{array}{c}\text { Zero } \\
- \\
\text { orde } \\
r\end{array}$ & $\begin{array}{c}\text { Partia } \\
1\end{array}$ & Part & $\begin{array}{c}\text { Toleranc } \\
\mathrm{e}\end{array}$ & VIF \\
\hline
\end{tabular}


Jurnal Akuntansi dan Keuangan (JAK)

Volume 6, No. 2 Oktober Tahun 2021

Page: 331 - 346

http://ojs.uho.ac.id/index.php/jak-uho/issue/archive

e-ISSN: 2088-4656

\begin{tabular}{|c|c|c|c|c|c|c|c|c|c|c|}
\hline $\begin{array}{l}\text { (Constant } \\
\text { ) }\end{array}$ & ,790 & ,353 & & 2,235 & $\begin{array}{r}, 02 \\
9\end{array}$ & & & & & \\
\hline $\mathrm{X} 1$ & ,420 & , 115 & ,430 & 3,645 & $\begin{array}{r}, 00 \\
1\end{array}$ & ,725 & 420, & 285, & ,441 & 2,266 \\
\hline $\mathrm{X} 2$ & 043 & 099 & ,054 & ,439 & $\begin{array}{r}\text {,66 } \\
2\end{array}$ & 631 & ,056 & ,034 & 401 & 2,496 \\
\hline X3 & ,323 & 098, & ,386 & 3,312 & $\begin{array}{r}, 00 \\
2\end{array}$ & ,710 & ,388 & 259, & ,451 & 2,218 \\
\hline
\end{tabular}

a. Dependent Variable: Y

Sumber : output yang diolah SPSS, 2021.

Berdasarkan hasil estimasi tabel di atas dengan menggunakan program SPSS 22

diperoleh nilai koefisien, sebagai berikut:

$\mathrm{Y}=\alpha+\mathrm{b} 1 \mathrm{X} 1+\mathrm{b} 2 \mathrm{X} 2+\mathrm{b} 3 \mathrm{X} 3+\mathrm{e}$

$Y=0,790+0,420 X 1+0,043 X 2+0,323 X 3+0,353$

Berdasarkan Estimasi Regresi Berganda di atas dapaat diuraikan sebagai berikut:

1. Koefisien regresi untuk varibel Sistem Akuntansi Pemerintah Daerah adalah 0,420 kali, dapat diartikan bahwa terdapat hubungan yang positif antara Sistem

Akuntansi Pemerintah Daerah terhadap Akuntabilitas Kinerja Instansi

Pemerintah. Sehingga dapat diartikan bahwa apabila variabel Sistem Akuntansi

Pemerintah Daerah terjadi kenaikan 1 kali, maka variabel terikat Akuntabilitas

Kinerja Instansi Pemerintah akan mengalami kenaikan sebesar 0,420 kali.

2. Koefisien regresi untuk varibel Pemahaman Akuntansi adalah 0,043 kali, dapat diartikan bahwa terdapat hubungan yang positif antara Pemahaman Akuntansi terhadap Akuntabilitas Kinerja Instansi Pemerintah. Sehingga dapat diartikan bahwa apabila variabel Pemahaman Akuntansi terjadi kenaikan 1 kali, maka variabel terikat Akuntabilitas Kinerja Instansi Pemerintah akan mengalami kenaikan sebesar 0,043 kali.

3. Koefisien regresi untuk varibel Ketaatan Pada Peraturan Perundangan adalah 0,323 kali, dapat diartikan bahwa terdapat hubungan yang positif antara Ketaatan Pada Peraturan Perundangan terhadap Akuntabilitas Kinerja Instansi Pemerintah. Sehingga dapat diartikan bahwa apabila variabel Ketaatan Pada Peraturan Perundangan terjadi kenaikan 1 kali, maka variabel terikat Akuntabilitas Kinerja Instansi Pemerintah akan mengalami kenaikan sebesar 
Jurnal Akuntansi dan Keuangan (JAK)

Volume 6, No. 2 Oktober Tahun 2021

Page: 331 - 346

http://ojs.uho.ac.id/index.php/jak-uho/issue/archive

e-ISSN: $2088-4656$

0,323 kali.

Berdasarkan hasil analisis regresi linear berganda juga dapat diketahui nilai korelasi dan koefisien determinasinya, dimana nilai korelasi mencerminkan kekuatan hubungan antara variabel independen/bebas (variabel sistem akuntansi pemerintah daerah, pemahaman akuntansi dan ketaatan pada peraturan perundangan) terhadap variabel dependen/terikat (akuntabilitas kinerja). Diketahui nilai koefisien determinasi sebesar 0.620. Nilai tersebut berarti seluruh variabel bebas kurang mampu dalam menjelaskan variabel dependen (akuntanbilitas kinerja) sebesar 62\%, sisanya sebesar $38 \%$ dipengaruhi oleh faktor-faktor lain.

\section{Pengujian Hipotesis}

a. Uji t (Parsial)

Uji parsial (t-test) bertujuan untuk mengetahui apakah masing- masing variabel independen mempengaruhi variabel dependen secara signifikan. Untuk pengujian secara parsial ini digunakan uji $t$. dapat disimpulkan mengenai hasil uji hipotesis secara parsial dari masing-masing variabel independen sebagai berikut :

1. Nilai signifikansi variabel sistem akuntansi pemerintah daeerah diperoleh tingkat signifikansi sebesar $0.001>0.05$ sedangkan nilai Ttabel adalah 1.660 sehingga nilai uji Thitung > Ttabel (3.645>1.660) maka hipotesis yang diajukan diterima. Hal ini berarti bahwa sistem akuntansi pemerintah secara parsial berpengaruh signifikan terhadap akuntanbilitas kinerja pada taraf signifikan $\alpha=$ 5\%. Diketahui nilai koefisien regresi dari sistem akuntansi pemerintah adalah 3.645. Karena bernilai positif hal ini berarti variabel sistem akuntansi pemerintah daerah memberikan dampak positif terhadap akuntanbilitas kinerja. Hasil penelitian ini menunjukkan bahwa sistem akuntansi pemerintah daerah mampu mempengaruhi akuntanbilitas kinerja pada OPD Pemerintah Daerah Kota Kendari.

2. Nilai signifikansi variabel pemahaman akuntansi diperoleh tingkat signifikansi sebesar $0.662>0.05$ sedangkan nilai Ttabel adalah 1.660 sehingga nilai uji Thitung < Ttabel $(0.439<1.660)$ maka hipotesis yang diajukan diterima. Hal ini berarti bahwa pemahaman akuntansi secara parsial berpengaruh signifikan terhadap akuntabilitas kinerja pada taraf signifikan $\alpha=5 \%$. Diketahui nilai 
Jurnal Akuntansi dan Keuangan (JAK)

Volume 6, No. 2 Oktober Tahun 2021

Page: 331 - 346

http://ojs.uho.ac.id/index.php/jak-uho/issue/archive

e-ISSN: $2088-4656$

koefisien regresi dari pemahaman akuntansi adalah 0.439. Karena bernilai positif, hal ini berarti variabel pemahaman akuntansi memberikan dampak positif terhadap akuntanbilitas kinerja (berpengaruh positif). Hasil penelitian ini menunjukkan bahwa pemahaman akuntansi mampu mempengaruhi akuntanbilitas kinerja pada OPD Pemerintah Daerah Kota Kendari.

3. Nilai signifikansi variabel ketaatan pada peraturan perundangan diperoleh tingkat signifikansi sebesar $0.002<0.05$ sedangkan nilai Ttabel adalah 1.660 sehingga nilai uji Thitung > Ttabel $(3.312>1.660)$ maka hipotesis yang diajukan diterima. Hal ini berarti bahwa ketaatan secara parsial berpengaruh signifikan terhadap akuntanbilitas kinerja pada taraf signifikan $\alpha=5 \%$. Diketahui nilai koefisien regresi dari ketaatan adalah 3.312. Karena bernilai positif, hal ini berarti variabel ketaatan pada peraturan perundangan memberikan dampak positif terhadap akuntanbilitas kinerja (berpengaruh positif) semakin naik ketaatan, maka semakin meningkat akuntanbilitas kinerja, pengaruhnya signifikan. Hasil penelitian ini menunjukkan bahwa ketaatan pada peraturan perundangan mampu mempengaruhi akuntanbilitas kinerja pada OPD Pemerintah Daerah Kota Kendari.

\section{b. Uji f ( Simultan)}

Uji signifikansi simultan F (uji-F) bertujuan untuk mengetahui apakah variabelvariabel independen secara bersama-sama mempengaruhi variabel dependen secara signifikan. Pengujian hipotesis dilakukan dengan cara membandingkan antara nilai signifikan F dengan nilai signifikansi yaitu 0,05 . Hasil uji simultan pada penelitian ini menunjukkan bahwa diketahui nilai $\mathrm{F}_{\text {hitung }}$ adalah 33.700, dengan nilai $\mathrm{F}_{\text {tabel }}$ sebesar 2.753 sehingga $\mathrm{F}_{\text {hitung }}>\mathrm{F}_{\text {tabel }}(33.700>2.753)$ dan nilai signifikan $0.000<0.05$, maka disimpulkan bahwa seluruh variabel bebas (sistem akuntansi pemerintah daerah, pemahaman akuntansi, dan ketaatan pada peraturan perundangan) secara simultan berpengaruh signifikan terhadap akuntanilitas kinerja.

\section{Pembahasan}

Nilai koefisien determinasi $\mathrm{R}^{2}$ terletak pada kolom $R$-Square. Diketahui nilai koefisien determinasi sebesar $\mathrm{R}^{2}=0.620$. Nilai tersebut berarti seluruh variabel indepeden kurang mampu menjelaskam variabel akuntabilitas kinerja sebesar $63 \%$, 
Jurnal Akuntansi dan Keuangan (JAK)

Volume 6, No. 2 Oktober Tahun 2021

Page: 331 - 346

http://ojs.uho.ac.id/index.php/jak-uho/issue/archive

e-ISSN: 2088-4656

sisanya sebesar $38 \%$ dipengaruhi oleh faktor-faktor lain.

\section{Pengaruh Sistem Akuntansi Pemerintah Daerah terhadap Akuntabilitas Kinerja Instansi Pemerintah Kota Kendari}

Hasil pengujian hipotesis pada variabel sistem akuntansi pemerintah daerah menunjukkan bahwa sistem akuntansi pemerintah daerah memiliki pengaruh dan signifikan terhadap akuntabilitas kinerja instansi pemerintah pada OPD Kota Kendari dan merupakan faktor penentu dalam peningkatan akuntabilitas kinerja instansi pemerintah pada OPD Kota Kendari.

Hasil penelitian ini sejalan dengan hasil penelitian yang dilakukan oleh Janny Rahmi Hasibuan, dkk (2018). Jika sebuah instansi memiliki kecenderungan pencatatan, penggolongan, dan pelaporan dilakukan secara sistematis dan objektif diharapkan akan meningkatkan kinerja instansi pemerintah. Berdasarkan hasil analisis jawaban responden diketahui bahwa indikator Pencatatan, Penggolongan, dan Pelaporan menunjukkan angka yang cukup tinggi. Hal ini menunjukkan bahwa OPD terkait telah melaksanakan pencatatan secara sistematis dan telah melakukan penggolongan secara lengkap dan terinci, memberikan laporan sesuai kronologis yang bersifat logis, objektif, dan faktual. Berdasarkan hal tersebut, dapat dijelaskan bahwa sistem akuntansi pemerintah daerah mempengaruhi akuntabilitas kinerja instansi pemerintah daerah pada OPD Kota Kendari.

\section{Pengaruh Pemahaman Akuntansi terhadap Akuntabilitas Kinerja Instansi Pemerintah Kota Kendari}

Hasil pengujian hipotesis pada variabel pemahaman akuntansi menunjukkan bahwa pemahaman akuntansi memiliki pengaruh terhadap akuntabilitas kinerja instansi pemerintah pada OPD Kota Kendari dan merupakan faktor penentu dalam peningkatan akuntabilitas kinerja instansi pemerintah pada OPD Kota Kendari. Hasil penelitian ini sejalan dengan hasil penelitian yang dilakukan oleh Janny (2018). Berdasarkan hasil analisis jawaban responden diketahui bahwa indikator Tingkat Pemahaman Terhadap Komponen Laporan Akuntabilitas dan Prinsip Akuntansi serta indikator Tingkat Pemahaman Terhadap Pengakuan Unsur-unsur dalam Laporan Akuntabilitas menunjukkan angka yang cukup tinggi. Hal ini menunjukkan bahwa disetiap OPD terkait telah menjalankan prinsip-prinsip akuntansi dengan tingkat pemahaman yang 
Jurnal Akuntansi dan Keuangan (JAK)

Volume 6, No. 2 Oktober Tahun 2021

Page: 331 - 346

http://ojs.uho.ac.id/index.php/jak-uho/issue/archive

e-ISSN: $2088-4656$

baik dan telah memenuhi unsur-unsur dalam laporan akuntabilitas dengan tingkat pemahaman yang baik. Berdasarkan hal tersebut, dapat dijelaskan bahwa pemahaman akuntansi memiliki pengaruh terhadap akuntabilitas kinerja instansi pemerintah pada OPD Kota Kendari.

\section{Pengaruh Ketaatan pada Peraturan Perundangan terhadap Akuntabilitas Kinerja}

\section{Instansi Pemerintah Kota Kendari}

Hasil pengujian hipotesis pada variabel Ketaatan pada Peraturan Perundangan menunjukkan bahwa Ketaatan pada Peraturan Perundangan memiliki pengaruh dan signifikan terhadap akuntabilitas kinerja instansi pemerintah pada OPD Kota Kendari dan merupakan faktor penentu dalam peningkatan akuntabilitas kinerja instansi pemerintah pada OPD Kota Kendari.

Hasil penelitian ini sejalan dengan hasil penelitian yang dilakukan oleh Janny Rahmi Hasibuan, dkk (2018). Jika sebuah instansi memiliki kecenderungan konsistensi dan standar teknis yang sesuai, sehingga yakin akan kemampuannya dalam menyelesaikan setiap permsalahan yang ada, maka akan menimbulkan kepuasan kerja dan diharapkan akan meningkatkan akuntabilitas kinerja instansi pemerintah. Berdasarkan hasil analisis jawaban responden diketahui bahwa indikator konsisten/perilaku profesional dan indikator Standar Teknis menunjukkan angka yang cukup tinggi. Hal ini menunjukkan bahwa pegawai disetiap OPD mampu menghindari atau menjauhkan dirinya dari tindakan menyimpang dan telah memenuhi persyaratan yang ada. Dengan demikian dapat dijelaskan bahwa ketaatan pada peraturan perundangan mempengaruhi akuntabilitas kinerja instansi pemerintah daerah pada OPD Kota Kendari.

Pengaruh Sistem Akuntansi Pemerintah Daerah, Pemahaman Akuntansi, dan Ketaatan pada Peraturan Perundangan terhadap Akuntabilitas Kinerja Instansi Pemerintah Kota Kendari secara simultan

Berdasarkan hasil uji simultan yang dilakukan Sistem Akuntansi Pemerintah Daerah, Pemahaman Akuntansi, dan Ketaatan pada Peraturan Perundangan berpengaruh secara bersama-sama terhadap Akuntabilitas Kinerja. Hasil penelitian ini terlihat dari nilai signifikansi $0.000<0.05$. Sehingga Hipotesis diterima. Hasil penelitian ini sejalan dengan hasil penelitian oleh Zirman, dkk (2010), Riantiarno dan Azlina(2011), 
Jurnal Akuntansi dan Keuangan (JAK)

Volume 6, No. 2 Oktober Tahun 2021

Page: 331 - 346

http://ojs.uho.ac.id/index.php/jak-uho/issue/archive

e-ISSN: $2088-4656$

Lumenta, dkk (2016) dan Janny Rahmi Hasibuan, dkk (2018).

\section{KESIMPULAN, IMPLIKASI, KETERBATASAN, REKOMENDASI}

\section{Kesimpulan}

Berdasarkan hasil penelitian, dapat diambil kesimpulan bahwa Sistem Akuntansi Pemerintah Daerah secara parsial dan simultan berpengaruh signifikan terhadap Akuntabilitas Kinerja Instansi Pemerintah Kota Kendari. Pemahaman Akuntansi secara parsial tidak berpengaruh signifikan terhadap Akuntabilitas Kinerja Instansi Pemerintah Kota Kendari, dan secara simultan berpengaruh signifikan terhadap Akuntabilitas Kinerja Pemerintah Daerah Kota Kendari. Ketaatan pada Peraturan Perundangan secara parsial dan simultan berpengaruh signifikan terhadap Akuntabilitas Kinerja Instansi Pemerintah Kota Kendari.

\section{Implikasi}

Berdasarkan hasil penelitian dan pembahasan, dikemukakan bahwa sistem akuntansi pemerintah daerah, pemahaman akuntansi, dan ketaatan pada peraaturan perundangan merupakan variable yang sangat penting dikarenakan dapat mempengaruhi akuntabilitas kinerja instansi pemerintah.

\section{Keterbatasan Penelitian}

Penelitian ini memiliki beberapa keterbatasan antara lain sebagai berikut :

1. Ruang lingkup penelitian ini masih terbatas hanya pada 22 OPD Kota Kendari.

2. Permasalahan yang diteliti hanya terkait dengan sistem akuntansi pemerintah daerah, pemahaman akuntansi, dan ketaatan pada peraturan perundangan serta akuntabilitas kinerja instansi pemerintah.

3. Jumlah informan yang diberi kuesioner.

\section{Rekomendasi}

Berdasarkan pembahasan dan kesimpulan yang telah diuraikan sebelumnya, maka peneliti dalam hal ini memberikan saran kepada Pihak instansi terkait diharapkan dapat lebih meningkat sistem akuntansi pemerintah daerah, pemahaman akuntansi dan ketaatan pada peraturan perundangan agar tercapai akuntanbilitas kinerja pemerintah daerah yang baik. Dikarenakan aspek tersebut memiliki pengaruh signifikan terhadap akuntabilitas kinerja Kota Kendari.Bagi peneliti berikutnya di masa mendatang agar 
Jurnal Akuntansi dan Keuangan (JAK)

Volume 6, No. 2 Oktober Tahun 2021

Page: 331 - 346

http://ojs.uho.ac.id/index.php/jak-uho/issue/archive

e-ISSN: $2088-4656$

dapat memperluas atau menambah sampel penelitian seperti dari luar Kota Kendari atau menambah periode pengamatan. Bagi peneliti berikutnya disarankan menambah variabel lain yang berkaitan erat secara teori terhadap variabel akuntabilitas kinerja seperti akuntabilitas keuangan dan pengendalian intern. Hal ini dimaksudkan agar variasi naik turunnya akuntabilitas kinerja dapat lebih dijelaskan.

\section{DAFTAR PUSTAKA}

Anthony dan Govindajaran, 2005. Manajement Control System, edisi 11, buku 2. Jakarta: Salemba Empat.

Darwanis dan Sephi Chairunnisa, 2013. Akuntabilitas Kinerja Instansi Pemerintah. Jurnal telaah \& riset akuntansi, Vol. 6, Nomor 2, Hal 150-174.

Instruksi Presiden RI Nomor 7,1999.“Akuntabilitas Kinerja Instansi Pemerintah”.

LAN, BPKP, 2000. Pengukuran Kinerja Instansi Pemerintah, Modul Sosialisasi Sistem Akuntabilitas Kinerja Instansi Pemerintah (AKIP), Lembaga Administrasi Negara, Jakarta.

Mardiasmo, 2002. Akuntansi sektor publik. Yogyakarta: Andi.

Mulyana, Budi. 2006. Pengaruh Penyajian Neraca Daerah dan Aksesibilitas Laporan Keuangan Terhadap Transparansi dan Akuntabilitas Pengelolaan Keuangan Daerah, Jurnal Akuntansi Pemerintah.

Rahmi Hasibuan, Janny. 2018. Pengaruh Penerapan Sistem Akuntansi Pemerintah Daerah, Pemahaman Akuntansi, dan Ketaatan pada Peraturan Perundangan Terhadap Akuntabilitas Kinerja Instansi Pemerintah pada SKPD Padang Lawas. Jurnal Akuntansi, Vol 6. No. 2. Universitas Sumatera Utara, Medan.

Riantiarno, Reynaldi dan Nur Azlina. 2011. Faktor-faktor yang Mempengaruhi Akuntabilitas Kinerja Instansi Pemerintah (Studi pada Satuan Kerja Perangkat Daerah Kabupaten Rokan Hulu). Pekbis Jurnal, Vol.3, No.3,560-568.

Sugiyono. 2014. Metode Penelitian Pendidikan Pendekatan Kuantitatif, Kualitatif, dan $R \& D$, Bandung: Alfabeta.

www.sultra.antaranews.com. Diakses tanggal 25 Oktober 2020, pukul 20:03.

Zirman, Edfan Darlis, dan R. Muhammad Rozi. 2010. Pengaruh Kompetensi Aparatur Pemerintah Daerah, Penerapan Akuntabilitas Keuangan, Motivasi Kerja, dan Ketaatan Pada Peraturan Perundangan Terhadap Akuntabilitas Kinerja Instansi Pemerintah. Jurnal Ekonomi, Vol. 18, Nomor 1, Maret 2010. 